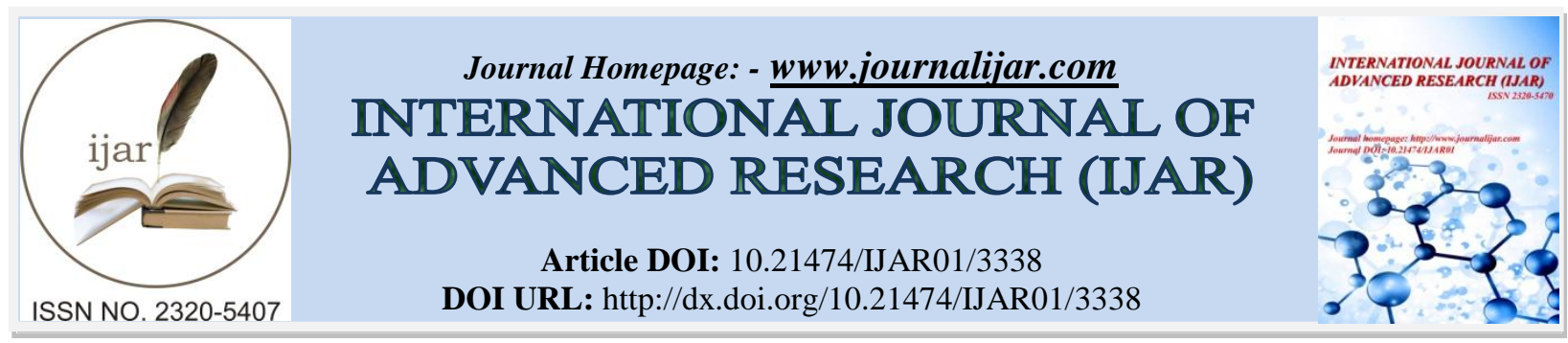

RESEARCH ARTICLE

\title{
EOSINOPHILIA STILL REMAINS THE GOLD STANDARD FOR THE DIAGNOSIS OF ALLERGIC NON NEOPLASTIC NASAL POLYPOIDAL LESIONS.
}

Arshdeep Kaur, Gurpreet Singh Sran, Manharjot Singh Malhi and Vijay Suri.

\section{Manuscript Info}

Abstract

Manuscript History

Received: 20 December 2016

Final Accepted: 28 January 2017

Published: February 2017

Copy Right, IJAR, 2017,. All rights reserved.

\section{Introduction:-}

Nasal polyps is the most common group of mass lesions encountered in the nose. ${ }^{1}$ Nasal polyps are a multifactorial disease, with infectious, non-infectious, inflammatory, anatomic and genetic abnormalities. Most theories consider polyps to be the ultimate manifestation of chronic inflammation. ${ }^{2}$ Nasal polyp is a relatively common condition found in 1-4\% of general population and in high percentage of some selected group of patients. Nasal polyps diagnosed clinically are not always inflammatory in origin. A variety of non-neoplastic and neoplastic conditions can present as nasal polyps. Though, inflammatory polyps are the commonest. ${ }^{3,4}$ Nasal polyps are pedunculated smooth, gelatinous, semi-translucent, round or pear shaped masses of inflamed mucosa of the nose and para-nasal sinuses prolapsing into the nose. Nasal polyposis is often associated with asthma, and other respiratory diseases like cystic fibrosis, primary ciliary dyskinesia, and aspirin sensitivity.

The site of polyp origin is a ${ }^{\text {particular }}$ narrow area in the upper part of the nose, lateral to the middle turbinate, and around the openings of the ethmoid and maxillary sinuses. This is a part where the mucous membranes come into close contact. 5

The etiology of nasal polyps is still unclear and currently no single theory adequately explains the formation of all nasal polyps. The two most frequently mentioned theories are based on allergic and infectious causes. Although nasal polyp tissue is known to contain a high level of histamine (Drake-Lee et al 1984), there are hardly any details in the literature regarding the distribution and abundance of mast cells in nasal polyp tissue. ${ }^{6}$ The present study is conducted to quantitate and study the localization of mast cells in nasal non- neoplastic polypoidal lesions of varied aetiology.

Nasal polyps are an available model for chronic airway inflammation research, since the biopsy is easy to obtain. Histologically, nasal polyps are characterized by a large number of inflammatory cells infiltration and structural modifications of the epithelium and lamina propria.

\section{Aims and objectives:-}

To calculate local and systemic eosinophilia.

\section{Material and method:-}

The present observational study was done in the department of pathology AIMSR over a period of one and a half 
year from $1^{\text {st }}$ April 2014 to $30^{\text {th }}$ September 2015. All patients with nasal polyps taken up for surgery were considered. The patients were evaluated clinically and history was taken. Ethical approval from institutional ethical committee of ADESH UNIVERSITY was taken before the start of the study. Proper informed consent was taken from all the patients.

\section{Inclusion Criteria:}

1. Only non-neoplastic lesions (eg. allergic, non-allergic like inflammatory, tuberculosis, rhinosporidiosis, fungal polyps etc.) of nose presenting as nasal polyp were taken up for study.

2. All patients of both sexes irrespective of socio economic status were taken up for the study.

\section{Exclusion Criteria:}

1. Patients with diagnosed neoplastic lesion (eg. Benign like inverted papilloma, transitional papilloma, angiofibroma and malignant like squamous cell carcinoma, adenocarcinoma, adenoid cystic carcinoma etc.) were excluded from the study.

The samples received were processed using standard technique and haematoxylin and eosin staining was done on all the samples. Only the polyps that were diagnosed as non-neoplastic polyps on H\&E were taken up for study.

\section{Observation:-}

Table-1:- Age And Sex Incidence Of Nasal Polyps

\begin{tabular}{|l|l|l|l|l|}
\hline Age & Male Number(\%) & Female Number(\%) & Total Number(\%) & Ratio Male:Female \\
\hline $0-10$ & $2(3.45)$ & $3(5.77)$ & $5(4.55)$ & 0.67 \\
\hline $10-20$ & $16(27.59)$ & $14(26.92)$ & $30(27.27)$ & 1.14 \\
\hline $20-30$ & $15(25.86)$ & $10(19.23)$ & $25(22.73)$ & .1 .50 \\
\hline $30-40$ & $12(20.69)$ & $10(19.23)$ & $22(20.00)$ & 1.20 \\
\hline $40-50$ & $6(10.34)$ & $7(13.46)$ & $.13(11.82)$ & 0.86 \\
\hline $50-60$ & $5(8.62)$ & $6(11.54)$ & $11(10)$ & 0.83 \\
\hline $60-70$ & $2(3.45)$ & $2(3.85)$ & $4(3.64)$ & 1.00 \\
\hline Total & $58(100.00)$ & $52(100.00)$ & $110(100.00)$ & 1.12 \\
\hline Mean & 29.87 & 30.73 & 30.30 & \\
\hline SD & 14.99 & 16.40 & .15 .60 &. \\
\hline
\end{tabular}

$\mathrm{P}$ value $=0.543$

Female patients outnumbered males in all decades except in $2^{\text {nd }}, 3^{\text {rd }}$, 4th and $7^{\text {th }}$ decade where males dominated females. Mean age in males was 29.87yrs and mean age in females was 30.73yrs. Overall mean age was 30.30yrs.

Table: 2:- Distribution Of Subjects According To Clinical Diagnosis

\begin{tabular}{|l|l|l|}
\hline Histopathology & Number & Percentage \\
\hline Allergic & 29 & 26.36 \\
\hline Non-allergic & 81 & 73.64 \\
\hline
\end{tabular}

$\mathrm{P}$ value $=0.000$

Non-allergic polyps (73.64\%) were significantly more than allergic polyps (26.36\%).

Table: 3:- distribution of different non-neoplastic polyps in different age groups according to the histopathological diagnosis.

\begin{tabular}{|c|c|c|c|c|}
\hline \multirow[t]{3}{*}{ Age } & \multirow[t]{3}{*}{ Allergic polyp } & \multicolumn{3}{|c|}{ Non- allergic polyps } \\
\hline & & \multirow[t]{2}{*}{ Non-specific inflammatory polyp } & \multicolumn{2}{|c|}{ Specific inflammatory polyp } \\
\hline & & & Tubercular & Fungal \\
\hline $0-10$ & - & 5 & & \\
\hline $10-20$ & 6 & 20 & 1 & 4 \\
\hline $20-30$ & 5 & 11 & 1 & 7 \\
\hline $30-40$ & 9 & 6 & & 7 \\
\hline $40-50$ & 4 & 7 & & 2 \\
\hline $50-60$ & 5 & 5 & & 1 \\
\hline $60-70$ & - & 4 & & \\
\hline TOTAL & 29 & 56 & 2 & 22 \\
\hline \multirow[t]{2}{*}{ Percentage } & \multirow[t]{2}{*}{26.36} & \multicolumn{3}{|c|}{73.64} \\
\hline & & 69.14 & 2.47 & 27.16 \\
\hline
\end{tabular}


Out of the total 110 cases, most of them were diagnosed as non-allergic polyps, with non-specific inflammatory being the most common (69.14), followed by fungal (27.16\%) and tubercular (2.47\%). Allergic polyps account for about $26.36 \%$ of the total polyp specimens received.

Table: 4:- gross examination of nasal polyps.

\begin{tabular}{|l|l|l|l|}
\hline Gross feature & & Number & Percentage \\
\hline \multirow{3}{*}{ Gross colour } & Grey white & 78 & 70.91 \\
\cline { 2 - 4 } & Grey brown & 29 & 26.36 \\
\cline { 2 - 4 } & Grey tan & 3 & 2.73 \\
\hline \multirow{2}{*}{ Gross consistency } & Soft & 108 & 98.18 \\
\cline { 2 - 4 } & Firm & 2 & 1.82 \\
\hline
\end{tabular}

Out of the total 110 cases, $70.91 \%$ cases were grey-white in colour, followed by grey brown(26.36\%) and minimum grey $\tan (2.73 \%)$.

Out of the total 110 nasal polyps, $98.98 \%$ (108 cases) were soft in consistency.

Table: 5:- Distribution Of Symptoms

\begin{tabular}{|l|l|l|}
\hline Symptoms & Number of cases & Percentage \\
\hline Nasal obstruction & 70 & 63.64 \\
\hline Nasal obstruction with epistaxis & 2 & 1.82 \\
\hline $\begin{array}{l}\text { Nasal obstruction with headache and } \\
\text { difficulty in breathing }\end{array}$ & 16 & 14.55 \\
\hline $\begin{array}{l}\text { Nasal obstruction with rhinorrhea } \\
\text { and sneezing }\end{array}$ & 21 & .19 .09 \\
\hline Ear pain & 1 & 0.91 \\
\hline Total & 110 & 110 \\
\hline
\end{tabular}

Nasal obstruction (70\%) was the commonest symptom followed by nasal obstruction with rhinorrhea and sneezing (19.09\%), nasal obstruction with headache and difficulty in breathing (14.55\%), nasal obstruction with epistaxis $(1.82 \%)$ and ear pain $(0.91 \%)$.

Figure 9: Distribution of symptoms.

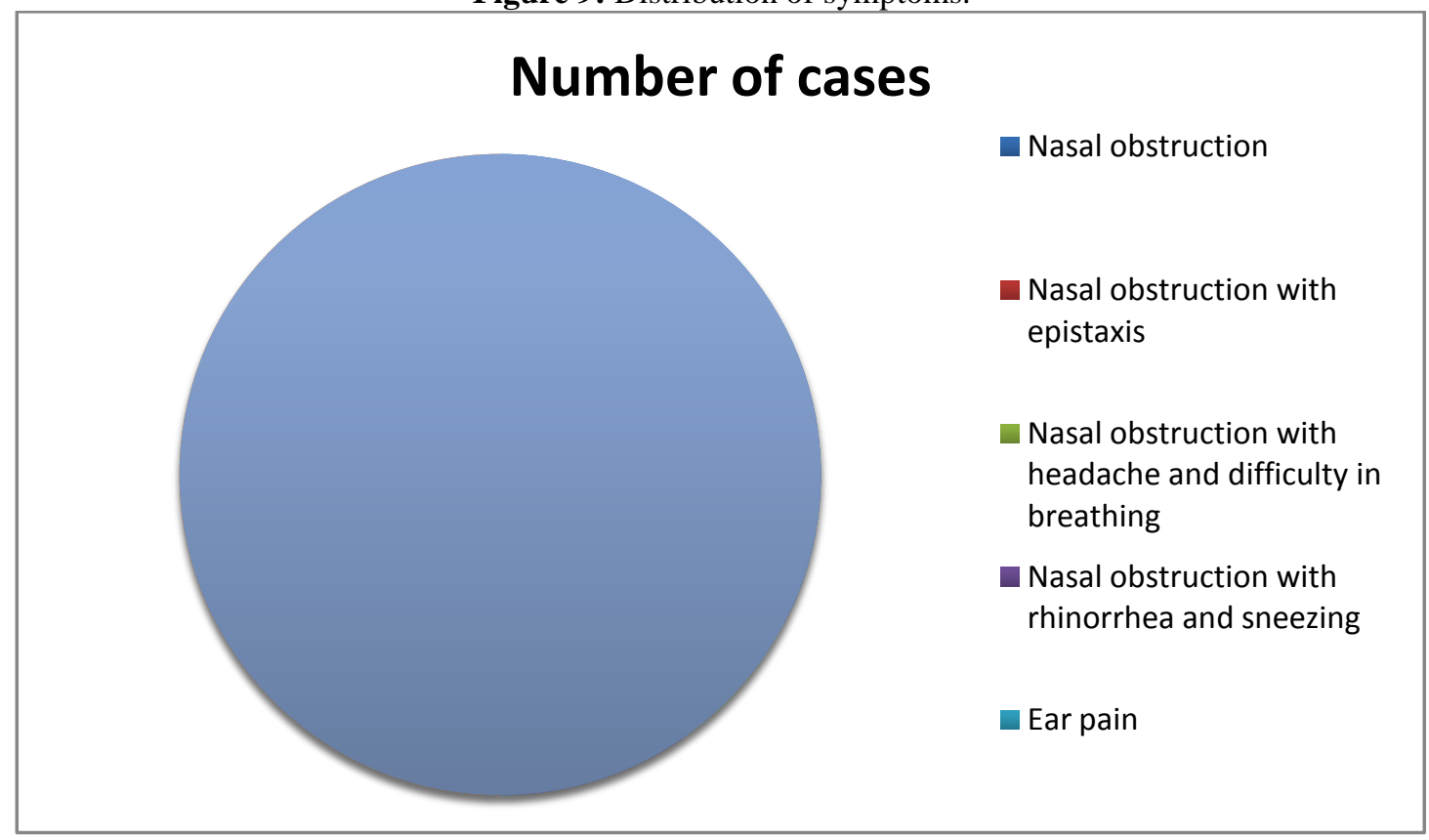

\section{Microscopic findings in polyps:-}

The type and density of inflammatory cell population was observed. Majority of the polyps had lymphocytes, plasma cells, eosinophils, neutrophils and macrophages. The polyps were distributed according to the predominance 
of stromal infiltrate which was mono-nuclear (comprising predominantly of lymphocytes and plasma cells) or eosinophil rich.

Table: 6:- Distribution According To Stromal Infiltrate

\begin{tabular}{|l|l|l|}
\hline Infiltrate & Number of cases & Percentage \\
\hline Predominance of mononuclear cells & 64 & 58.18 \\
\hline Predominance of eosinophils & 46 & 41.82 \\
\hline Total & 110 & 100 \\
\hline
\end{tabular}

$58.18 \%$ (64 cases) of the nasal polyps showed predominance of mononuclear cell infiltrate and $41.82 \%$ (46 cases) showed eosinophil predominance.

Table: 7:- Distribution According To Absolute Eosinophil Count In Patients Of Nasal Polyps

\begin{tabular}{|l|l|l|l|l|}
\hline AEC & Allergic & Non-allergic & \\
\hline & Number & Percentage & Number & Percentage \\
\hline $0-500$ & 4 & 13.79 & 78 & 96.30 \\
\hline $501-1000$ & 21 & 72.41 & 2 & 2.47 \\
\hline $1001-1500$ & 3 & 10.34 & 0 & 0.00 \\
\hline $1501-2000$ & 1 & 3.45 & 1 & 1.23 \\
\hline Mean & 789.83 & & 220.26 & \\
\hline SD & 328.17 & & 223.43 & \\
\hline
\end{tabular}

$\mathrm{P}$ value $=0.000$

Significant peripheral eosinophilia was seen in $72.4 \%$ ( 21 cases) of allergic polyps with most common range of 5011000eosinophils per $\mathrm{mm}^{3}$. Maximum absolute eosinophil count was 1824 eosinophils $/ \mathrm{mm}^{3}$ and minimum was 248 eosinophils per $\mathrm{mm}^{3}$. In case of non-allergic polyps, eosinophils were in range of 0-500eosinophils per $\mathrm{mm}^{3}$ in $96.3 \%$ (78 cases), with a maximum of 1632 eosinophils $/ \mathrm{mm}^{3}$, seen in only one fungal polyp.

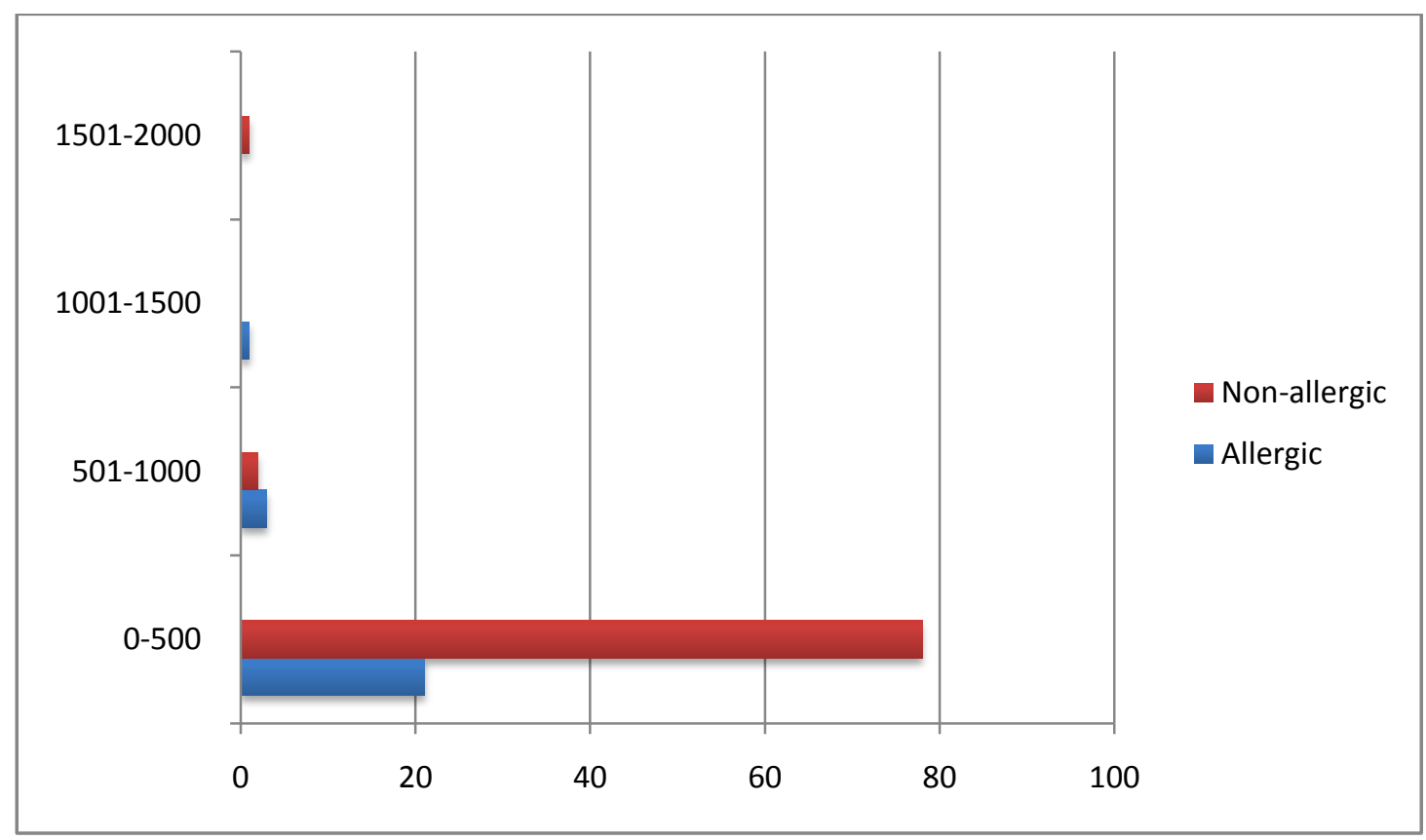

Figure 14: Distribution of nasal polyps according to the absolute eosinophil count.

Peripheral eosinophilia levels: Absolute eosinophil count was determined in blood sample of both study and control groups. More than or equal to 500eosinophils per micro litre is considered as systemic eosinophilia. 
Table: 8:- Peripheral Eosinophil Count In Patients Of Nasal Polyps

\begin{tabular}{|l|l|l|l|}
\hline \multicolumn{2}{|l|}{ Peripheral eosinophilia } & Cases & Percentage \\
\hline \multirow{2}{*}{ Non-allergic polyps (29) } & Present & 3 & 3.70 \\
\cline { 2 - 4 } & Absent & 78 & 96.30 \\
\hline \multirow{2}{*}{ Allergic polyps (81) } & Present & 25 & 86.21 \\
\cline { 2 - 4 } & Absent & 4 & 13.73 \\
\hline
\end{tabular}

$\mathrm{P}=0.000$

So, in our study, $86.21 \%$ (25 cases) of allergic polyps and 3.7\% (3 cases) of non-allergic polyps showed significant peripheral eosinophilia.

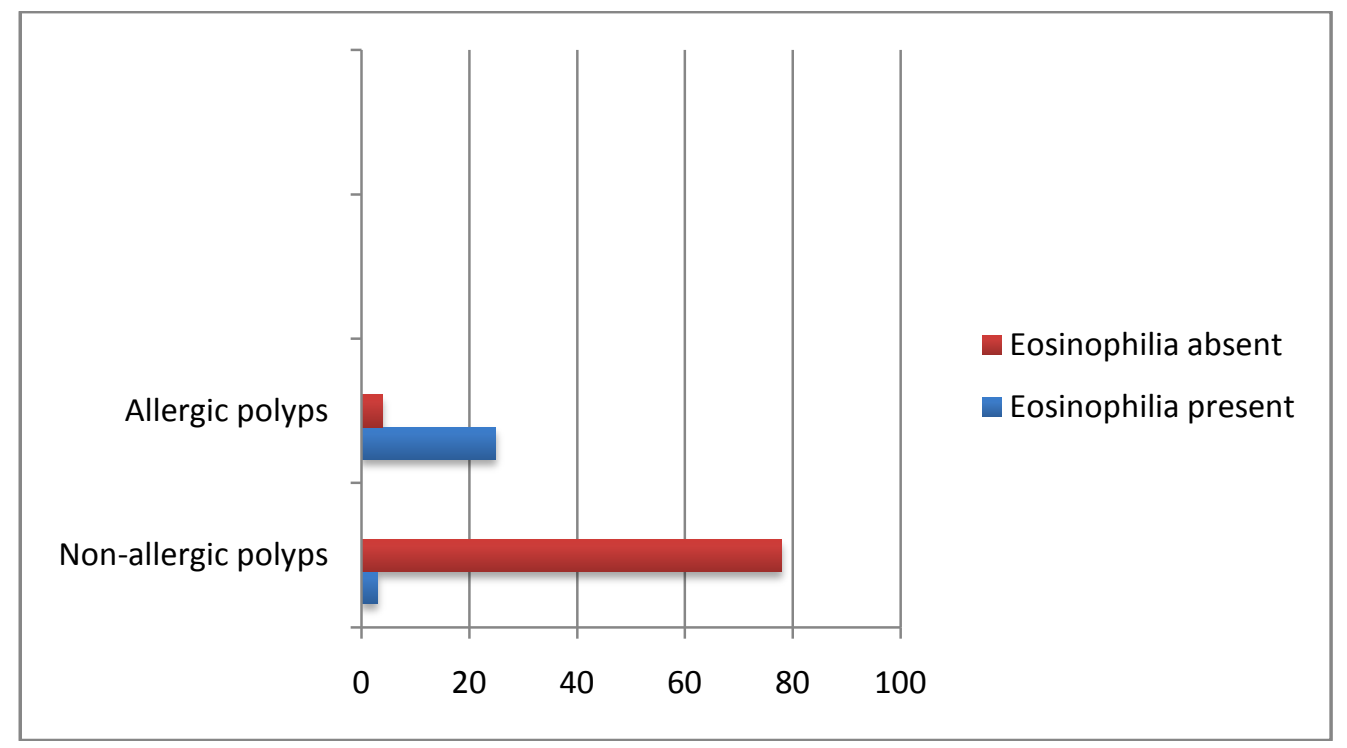

Table: 9:- Local Eosinophilia In Allergic And Non-Allergic Nasal Polyps

\begin{tabular}{|l|l|l|l|l|l|}
\hline Group & Number & Present & & \multicolumn{2}{l|}{ Absent } \\
\hline & & & & & \\
\hline Allergic & 29 & 29 & 100.00 & 0 & 0.00 \\
\hline Non-allergic & 81 & 16 & 19.75 & 65 & 80.25 \\
\hline
\end{tabular}

$\mathrm{p}$ value $=0.003$

In our study, eosinophilia was seen in $100 \%$ of cases of allergic polyps and $19.75 \%$ of cases of non-allergic polyps.

\section{Eosinophil count in stroma:-}

The histological examination of the slide for calculating local eosinophil count were performed. In total of 10 representative fields of inflammatory infiltrate density on each slide were counted with relation to eosinophils. These counts were converted to the average cells per high power field. The average cells per high power field more than or equal to 20 were taken as significant local eosinophilia for statistical analysis.

Table-10:- Eosinophil Count In Strom Of Nasalpolyps.

\begin{tabular}{|l|l|l|l|}
\hline & Eosinophilia & Cases & Percentage \\
\hline \multirow{2}{*}{ Non-allergic polyps } & Present & 16 & 14.55 \\
\cline { 2 - 4 } & Absent & 65 & 59.09 \\
\hline \multirow{2}{*}{ Allergic polyps } & Present & 29 & 26.36 \\
\cline { 2 - 4 } & Absent & - & 0.00 \\
\hline Total & 110 & 100.00 \\
\hline
\end{tabular}

Significant local eosinophilia was seen in $29 \%$ of allergic and $16 \%$ of non- allergic polyps. 
Table: 11:- Percentage Of Eosinophils In Stroma Of Nasal Polyps

\begin{tabular}{|l|l|l|l|}
\hline Percentage of eosinophils & Allergic polyp & Non-allergic polyp & Total (percentage) \\
\hline$<5 \%$ & - & 8 & $8(7.27 \%)$ \\
\hline $5-19 \%$ & - & 57 & $57(51.82 \%)$ \\
\hline $20-50 \%$ & 14 & 16 & $30(27.27 \%)$ \\
\hline$>50 \%$ & 15 & - & $15(13.64 \%)$ \\
\hline
\end{tabular}

In our study, most of the nasal polyps (51.82\%) showed 5-19\% eosinophils per high power field. In allergic polyps, all the nasal polyps showed $>20 \%$ eosinophils out of which about $50 \%$ had more than $50 \%$ eosinophils per hpf.

Correlation between peripheral and systemic eosinophilia:

Table: 12:- Correlation Between Peripheral And Systemic Eosinophilia In Nasal Polyps

\begin{tabular}{|l|l|l|l|}
\hline Eosinophilia eosinophilia & Local eosinophilia absent & Local eosinophilia present & Total \\
\hline $\begin{array}{l}\text { Systemic } \\
\text { absent }\end{array}$ & 17 & 82 \\
\hline $\begin{array}{l}\text { Systemic eosinophilia } \\
\text { present }\end{array}$ & 2 & 26 & 28 \\
\hline Total & 67 & 43 & 110 \\
\hline
\end{tabular}

(p-value <0.00001)

Our study showed that there is a significant correlation between local and systemic eosinophilia.

TABLE: 13:- Relation Between Eosinophils And Clinical Symptoms In Nasal Polyps

\begin{tabular}{|l|l|l|}
\hline Symptoms & Eosinophils & Standard deviation \\
\hline & Mean & 9.40 \\
\hline Nasal obstruction & 10.43 & 10.61 \\
\hline Nasal obstruction with epistaxis & 17.50 & 21.02 \\
\hline $\begin{array}{l}\text { Nasal obstruction with headache and } \\
\text { difficulty in breathing }\end{array}$ & 28.74 & 13.74 \\
\hline $\begin{array}{l}\text { Nasal obstruction with rhinorrhea } \\
\text { and sneezing }\end{array}$ & 54.76 & - \\
\hline Ear pain & 20.00 & \\
\hline P-value & 0.000 & \\
\hline
\end{tabular}

Significant relation was also seen between the percentage of eosinophils and clinical presentation of nasal obstruction, rhinorrhea and sneezing.

\section{Discussion:-}

Table: 14:- Comparative Study Of Age Distribution Of Nasal Polyps

\begin{tabular}{|l|l|l|l|}
\hline Patient age (years) & Busuttil $^{7}(1992)$ & Dandapath $^{8}(1993)$ & $\begin{array}{l}\text { Present study } \\
(2015)\end{array}$ \\
\hline $0-10$ & - & $4(3.54 \%)$ & $5(4.55 \%)$ \\
\hline $11-20$ & $2(2.7 \%)$ & $36(31.86 \%)$ & $30(27.52 \%)$ \\
\hline $21-30$ & $16(21.62 \%)$ & $44(38.94 \%)$ & $25(22.73 \%)$ \\
\hline $31-40$ & $19(25.67 \%)$ & $13(11.5 \%)$ & $22(20 \%)$ \\
\hline $41-50$ & $19(25.67 \%)$ & $9(7.96 \%)$ & $13(11.82 \%)$ \\
\hline $51-60$ & $6(8.1 \%)$ & $7(6.2 \%)$ & $11(\%) 10$ \\
\hline $61-70$ & $6(8.1 \%)$ & - & $4(3.64 \%)$ \\
\hline $71-80$ & $6(8.1 \%)$ & - & - \\
\hline Total & 74 & 113 & $110(100 \%)$ \\
\hline
\end{tabular}

In the present study, the youngest patient was 5 years old and oldest 69 years. Majority of patients were in the second decade [27.52\%] and fourth decades [22.73\%] of life, followed by 3rd decade [20.00\%], 5th decade [11.82\%], 6th decade [10.00\%], 1st decade [4.55\%], and least was in 7th decade [3.64\%].

According to Busuttil et all(1978), nasal polyps were more common in the $4^{\text {th }}$ and $5^{\text {th }}$ decade so, their results did not correlate with our study. ${ }^{7}$ 
Dandapath et al(1993) observed 2nd and 3rd decade as the most common age group affected. The present study correlated with the study of Dandapath et al in which nasal polyps were common in second decade of life. ${ }^{8}$

According to KirtsreesakulV(2005), in the general population, the overall prevalence rate of nasal polyps in adults is about $4 \%$. The prevalence is much lower in children, except nasal polyps usually occurs in the age group of $30-$ 60 years when associated with cystic fibrosis. In the present study children are the less commonly affected group $[4.55 \%, 5 \text { cases }]^{9}$

Klossek et al(1997) reported mean age for nasal polyps patients was $49.4 \pm 17.6$ years. ${ }^{10}$

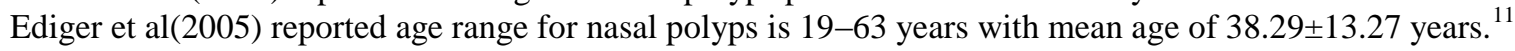

According to a study conducted by Pradhananga et al(2008), the patients of all age group present with nasal polyps with the peak age of 50 and above. In their study, nasal polyps were found in age range from 14 to 85 years with mean age of $40.33 \pm 17.4$ years and the maximum number of the patients $(37.2 \%)$ was in the age group of 20 40years, ${ }^{12}$ whereas in our study, mean age was $30.3 \pm 15.60$ years.

So as in our study the mean age was lower than all these studies, it may be because this region is more prone to infections, air pollution and allergies as compared to the other regions.

Table: 15:- Comparison Of Distribution Of Symptoms

\begin{tabular}{|c|c|}
\hline Study & No of cases \\
\hline Sethi et al ${ }^{13}(1998)$ & 6 \\
\hline Triglia and Nicollas $^{14}$ (1997) & 46 \\
\hline 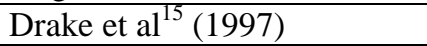 & 200 \\
\hline Present study & 109 \\
\hline
\end{tabular}

In other studies as well, nasal obstruction was the predominant symptom, which is in concordance with the present study.

Same results were obtained by Shulbha and Dayananda, that is both in non- allergic and allergic polyps, the commonest symptom was nasal obstruction, which was found to be statistically significant $(P<0.001)^{16}$

\section{Comparison of local and systemic eosinophilia:-}

According to Wardlaw et $\mathrm{al}^{17}$ (2000), the hypothesis that eosinophils are important effector cells in allergic disease rests on the evidence that the eosinophils are found in tissues in allergic diseases, their mediators are relevant to the disease process and removal of eosinophils is associated with an improvement in the disease. GCs undoubtedly have a profound effect on eosinophils and their beneficial effects in allergic disease appear to go hand-in- hand with their inhibition of tissue eosinophilia, but they are of course broad- spectrum anti-inflammatory drugs. ${ }^{17}$

There is no doubt that eosinophils are intimately associated with asthma and the other atopic diseases. As there is virtually no evidence that eosinophils can ameliorate disease, we presume they must either be bystander cells or actively involved in pathogenesis. The current evidence is consistent with a role for eosinophils simply as markers of the inflammatory process. Perhaps eosinophils are part of a complex inflammatory process in which they favoursome aspect of the pathophysiology.

So, more work needs be done to determine the extent to which the eosinophilia might guide management of nasal polyps. $^{17}$

Zhang et $\mathrm{al}^{18}$ (2008) also assessed the infiltration and activation of eosinophils in nasal polyps immunohistochemically. They concluded eosinophilia is a prominent histological feature of nasal polyps, which indicates that the activated eosinophils may play vital role in the pathogenesis of nasal polyps.

According to Pradhananga et $\mathrm{al}^{19}$ (2008), there is significant correlation between local and systemic eosinophilia. Thus this study correlated with our findings.

Table: 16:- Comparison Of Number Of Eosinophils Per Hpf

\begin{tabular}{|l|l|l|}
\hline \multirow{2}{*}{ Study } & No. ofeosinophils per hpf \\
\cline { 2 - 3 } & Allergic nasal polyps & \\
\hline Aleksander et al ${ }^{18}$ & $55.92 \pm 5.82$ & $11.12 \pm 2.03$ \\
\hline Present study & $59.89+\_16.48$ & $15.68+\ldots 7.69$ \\
\hline
\end{tabular}

The study done by Bryson et $\mathrm{al}^{20}$ (2003) on biopsy of diseased sinonasal tissue from 116 patients undergoing endoscopic sinus surgery and 24 control group with normal nasal mucosa undergoing septal surgery showed that the area of inflammatory infiltrate density and the numbers of eosinophils were high in patients with nasal polyps $(\mathrm{p}<0.0001)$ and also it has significant correlation with degree of the polyps $(\mathrm{p}=0.0017)$.

The results were similar to the results of our study in terms of local and systemic eosinophilia. 
Table: 17:- Comparison Of Percentage Of Eosinophils Per Hpf

\begin{tabular}{|l|l|l|}
\hline Percentage of eosinophils & ${\text { Luis et } \mathrm{al}^{21}(2008)}$ & Present study \\
\hline$<5 \%$ & $3(7.5 \%)$ & $8(7.27 \%)$ \\
\hline $5-19 \%$ & $5(12.5 \%)$ & $57(51.82 \%)$ \\
\hline $20-50 \%$ & $17(42.5 \%)$ & $30(27.27 \%)$ \\
\hline$>50 \%$ & $15(37.5 \%)$ & $.15(13.64 \%)$ \\
\hline
\end{tabular}

The study by Garin et $\mathrm{al}^{21}$ (2008) showed that most of the nasal polyps showed 20-50\% eosinophils per high power field but this study did not correlate with our study, as in our study most polyps had 5-19\% eosinophils.

\section{Conclusion:-}

A male predominance was seen in the study with a male to female ratio of 1.12:1.

Most of the patients presented with the clinical features of nasal obstruction and a few presented with epistaxis, headache, rhinorrhea and sneezing and only one case presented with ear pain.

Out of the total 110 cases, $26.36 \%$ were allergic nasal polyps and $73.64 \%$ were non- allergic nasal polyps.

Eosinophilia- local and peripheral:

All the allergic polyps and about $20 \%$ of non-allergic polyp showed local eosinophilia in tissue sections. The percentage of eosinophils was more in allergic polyps than in non- allergic polyps in histology sections.

About $86 \%$ of the allergic polys and only $3.7 \%$ of non-allergic polyps showed peripheral eosinophilia. Hence, significant peripheral eosinophilia was seen in allergic nasal polyps compared to non-allergic nasal polyps. Thereby a direct significant correlation was seen between peripheral and local eosinophilia in our study.

An increase in the percentage of eosinophils was associated with symptoms of nasal obstruction, rhinorrhea and sneezing.

\section{Bibliography:-}

1. Slavin RG. Nasal polyps and sinusitis. In: Middleton E, Reed CE, Adikinson EFE, Yunginger and William. Allergy Principle and practice Vol 2, New York: Mosby;1993. Pp1455-9.

2. Kirtsreesakul V. Update on nasal polyps: Etiopathogenesis. J Med Assoc Thai. 2005;88(12):1966-72.

3. Kumar V, Abbas AK, Robbins FN, Cotran Pathological Basis Of Disease, $7^{\text {th }}$ ed. Philadelphia: Saunders; 2004. Pp. 784-789.

4. Diamantopoulos I, James NS, Lowe J. All nasal polyps need histopathological examination: an adult based appraisal of clinical practice. Journal of Laryngology and Otology 2000;114:755-9.

5. Stamm AC. Microendoscopic surgery of paranasal sinuses and skull base $.1^{\text {st }}$ ed. New York: Springer-Verlag; 2000.

6. MysorekarVV ,Dandekar CP, Saraswati SG. Mast cell quantitation in non-neoplastic polypoidal nasal lesions. Indian Journal of Otolaryngology and Head and Neck Surgery 2004;56(2):87-88.

7. Busuttil A, Chandrachud H, Kerr AIG, Meudell G. Simple nasal polyps and allergic manifestations. J LaryngolOtol 1978; $92: 477-87$.

8. Dandapath A, Banerjee DK, Sanyal S, Roy M, Bhattcharjee A, Basu A. Nasal polyP : A Clinicohistological study. Ind J Otolaryngol Head Neck Surg 1993;2(4):219-222.

9. Kirtsreesakul V. Update on nasal polyps :Etiopathogenesis. J Med Assoc Thai 2005;88(12):1966-72.

10. Klossek JM, Peloquin L, Friedman WH, Ferrier JC, Fontanel JP Diffuse nasal polyposis: postoperative longterm results after endoscopic sinus surgery and frontal irrigation. Otolaryngol Head Neck Surg Oct. 1997; 117(4):355-61.

11. Ediger D, Sin BA, Heper A, AnadoluY ,Mésérlégil Z. Airway inflammation in nasal polyposis: immunopathological aspects of relation to asthma. Clinical \& Experimental Allergy 2005;35:319.

12. Majumdar B, Bull PD. The incidence and bacteriology of maxillary sinusitis in nasal polypsis. J LaryngolOtol 1982;96: 937-41.

13. Sethi DS, Lau DPC, Chee LWJ, Chong V. Isolated sphenoethmoid recess polyps. The journal of Laryngology and Otology 1998;112:660-3.

14. Triglia JM, Nicollas R. Nasal and Sinus Polyposis in Children. Laryngoscope 1997;107:963-6.

15. Drake-Lee AB. Nasal Polyps. In: Mackay IS, Bull TR edt. Scott Brown's Otolaryngology and Rhinology, $6^{\text {th }}$ 
edt., Oxford: Butterworth Heinemann;1997;10(15) Pp. 1-4.

16. V. S. Shulbha and B. S. DayanandaClinicopathological study of nasal polyps with special reference to mast cells in inflammatory polyps Basic and Applied Pathology 2012;5:59-62.

17. A J Wardlaw, C Brightling, R Green, G Woltmann and I Pavord. Division of Respiratory Medicine, Institute for Lung Health, University of Leicester School of Medical, Glenfield Hospital, Leicester, U British Medical Bulletin, The British Council 2000;56(4): 985-1003.

18. AleksandarPeric, DaniloVojovdic, BiserkaVukomanovic, and NenadBaletic. Eosinophilic inflammation in allergic rhinitis and nasal polyposis, inflammatory mediaators in allergic rhinitis and nasal polyposis. ArhHigRadaTokiskol 2011;62:341-348.

19. R. B. Pradhananga, A. Shrestha, B. Pradhan, R. C. Adhikari Local and systemic eosinophilia in patients with nasal polyps Journal of Institute of Medicine, December 2008;30(3):8-12

20. Bryson JM, Tasca RA \&. Rowe-Jones JM. Local and systemic eosinophilia in patients undergoing endoscopic sinus surgery for chronic rhinosinusitis with and without polyposis. Clin. Otolaryngol 2003;28: 55-8.

21. LuisGarín, MiguelArmengot, JoséRamónAlba, and CarmenCarda Correlations Between Clinicaland Histological Aspects in Nasal Polyposis ActaOtorrinolaringol Esp. 2008;59(7):315-20. 